\title{
Paper, Commerce, and the Circulation of News: A Case Study from Early Modern Malta
}

\author{
WILLIAM ZAMMIT \\ University of Malta
}

\section{Introduction}

The increasing availability of paper and its use as a medium for written and visual communication, whether in manuscript or printed format, together with the processes through which this transformed commerce and the communication of news in early modern Europe, has been the focus of a number of studies at both the macro and micro levels. The evolving, interdependent and intricate nature of the relationship between paper, manuscript and print was to prove of paramount importance in the evolution, among other things, of modern European commercial and business transactions, structures and networks, as well as in the dissemination and hence availability of news both as a political tool in the hands of the rising state and for the formation of public opinion when it percolated beyond the strictly political confines. ${ }^{1}$

The aim of this paper is to provide a case study of the interplay between paper, commerce and the dissemination of news - the latter in various typologies and through different media. In other words, it concentrates on the transformative power of this relationship within a specific peripheral European, geographical, political and cultural entity; one which aptly fits into Braudel's category of 'isolated worlds. ${ }^{2}$ Early modern Mediterranean islands often remained archaic in practically every aspect, unless and until what Braudel described as 'some accidental change of ruler or of fortune' took place, resulting in a sometimes short-lived, sometimes long-term, if not permanently maintained political, commercial and cultural integration with mainland Europe.

In this context, Malta provides a significant example. The island's 'historical accident' took place in 1530 when it became home of the Hospitaller and Sovereign Military Order of St. John. ${ }^{3}$ A cosmopolitan and aristocratic order with members

1 William J. Buxton, Michael R. Cheney and Paul Heyer, eds, Harold Innis's History of Communications: Paper and Printing - Antiquity to Early Modernity (Lanham: Rowman \& Littlefield, 2015), chapter 1, provides a succinct analysis of the wider availability of paper in the context of the broad political, religious, economic and cultural scenarios in which its availability thrived.

2 Fernand BRAUdel, The Mediterranean and the Mediterranean World in the Age of Philip II (London: Fontana-Collins, 1981), I, 149.

3 The early modern phase of Maltese history is customarily considered to cover the period of the Hospitaller and Military Order of St. John's presence and rule in Malta, that is, between 1530 and 1798. The fact that the order's central administration moved over to Malta, from where it conducted its diplomatic and military activities and where hundreds of its members resided, constituted a marked

Cromohs (Cyber Review of Modern Historiography), ISSN 1123-7023, 23/2020

(C) 2020 The Authors. This is an open access article published by Firenze University Press under the terms of the Creative Commons Attribution Licence, which permits use, distribution and reproduction in any medium, provided the original work is properly cited

DOI: $10.36253 /$ cromohs-12041 
hailing from across Europe, a good number of whom were very well politically and culturally connected, the order's presence was to set in motion a process of integration with Europe on all levels. Geographically cut off from the very southern fringe of Europe by a stretch of sea, the crossing of which depended as much upon the vagaries of the weather as political stability in the Mediterranean and - above all - the strength of the Muslim corsairing presence, the island, given the Hospitaller takeover, was to establish permanent and heavily sustained political and economic links with the harbours of the Italian peninsula, France and Spain, among others, and from there with practically all areas of Catholic Europe. ${ }^{4}$ Its economic contacts extended to Islamic North Africa and the Eastern Mediterranean. ${ }^{5} \mathrm{~A}$ cultural and economic backwater, more akin to North Africa than even to nearby Sicily, in most respects, pre1530 Malta would be integrated within the European fold in the process. ${ }^{6}$ The extent to which these processes of 'opening up' the island, as it were, depended upon a dramatic increase in the presence of paper and in its utilisation particularly for business transactions and the communication of news, while not unique to early modern Malta, is certainly worth exploring.

\section{Paper and the Expansion of Print Culture in Hospitaller Malta}

As was the case of other fringe regions in early modern Europe, the condition of preHospitaller Malta, with a population of just around 25,000, of whom only the miniscule lay and ecclesiastical elites were literate, imposed considerable limitations upon the presence of paper for private and business needs, whether in manuscript or, even more so, in print format. The lack of local paper production and printing facilities undoubtedly did little to help in this respect either. ${ }^{7}$ Even allowing for losses over time and the possible discovery of pre-1530 documentation of a personal and commercial nature, the limited utilisation of paper and written communication of a private, noninstitutional nature was in line with that of other small, isolated Mediterranean communities.

\footnotetext{
difference from the previously scantily populated island's status as a remote outpost of the Aragonese crown between 1283 and 1530 .

${ }^{4}$ The literature on this is quite extensive. On the activity of the order's fleet in this respect, see JOSEPH F. GRIMA, The Fleet of the Knights of Malta (Malta: BDL Publishers, 2016). On the activity pertaining to the maritime contacts established by the rising class of Maltese merchants, see CARMEL VASSALLO, Corsairing to Commerce: Maltese Merchants in XVIII Century Spain (Malta: Malta University Publishers, 1997). ${ }^{5}$ JOAN ABELA, Hospitaller Malta and the Mediterranean Economy in the Sixteenth Century (Woodbridge: The Boydell Press, 2018), especially chapter 4.

${ }^{6}$ IOAN. QuinTINI, Insulae Melitae Descriptio ex Commentariis Rerum Quotidianarum (Lyons: Sebastianus Gryphium, 1536). The author described the island as culturally African, going into such details as the inhabitants' appearance, clothing, way of life and housing. This contrasts with the various later travelogues which consistently referred to Malta's European and cosmopolitan nature.

${ }^{7}$ No attempt at the production of paper in Malta is known, except for the instance in 1850 which, however, never took off. See the pamphlet entitled Prospetto pel lo stabilimento di una fabbrica di carta nell'isola di Malta (Malta, 1850). In this case, the initiative was taken by relatives of Luigi Tonna, one of the first Maltese to set up a private printing press on the island following the granting of press freedom in January 1839.
} 
On an institutional level, however, what survives of the major pre-1530 Maltese archival fonds intended for permanent retention - namely that of the universitas, that is, the Maltese local commune; of the cathedral chapter and bishop's court; and the notarial archive - constitute but a part of their original extent. Outside the island, the state archive of Palermo contains the largest-known collection of paper documentation originating from Malta prior to the Hospitaller phase. Limited as they must have been, private trade contacts between the island and its Mediterranean neighbours, particularly Sicily, would have also necessitated the creation of additional paperwork, of which little trace now survives at least in public archival repositories. An analysis of fourteenth-century paper fragments and the more substantial material from the following century from Maltese archives is certainly a desideratum in this respect as it may reveal as yet unsuspected trade contacts between the island, the rest of the Mediterranean and possibly beyond. ${ }^{8}$

By the mid-sixteenth century, a series of developments were to result in a rather dramatic increase in the degree of manuscript and print requirements on the island and, hence, requirements for paper. The more permanent presence of the Hospitaller Order led to an influx of human and material resources into what had by then become the definite choice for its residence. The expansion of the state's administrative machinery, but also more refined interests, both on the part of the individual Hospitallers as well as the local elites, resulted in a steep increase in the presence of paper both for administrative as well as cultural purposes. After 1575, the Tridentine enactments regarding parochial record-keeping were put into practice on a regular basis by the ever-increasing number of parishes on the island. Coinciding with this was the establishment of the Roman Inquisition as a separate entity from the diocesan one. In the local case, this assumed the form of both an inquisition and apostolic delegation. Besides the substantial number of criminal and civil cases, running into many thousands by 1797, the new institution maintained a regular flow of correspondence with the Congregation of the Holy Office as well as with the papal Secretariat of State.

The necessity for an increased and regular supply of paper of different qualities resulted in the state's regulation of paper imports, establishing this commerce on a more permanent footing. By the early seventeenth century at the latest, monopolies for the importation of an ever-increasing amount of paper were being awarded to

\footnotetext{
8 BURns, 'The Paper Revolution,' 8 refers to a document from 1267 describing a cargo which included 'paper of Murcia' sailing from Barcelona to Sicily and other areas. This paper may have reached Malta directly from Iberian harbours or via Sicily, but this can only be confirmed through a physical study of pre-1530 Maltese archival paper. During the late thirteenth to the early fifteenth centuries what was described as 'cartis de papiro' were imported from Sicily for the use of the secular and ecclesiastical setups in Malta. See STAnley FIORInI, ed., Documentary Sources of Maltese History: Part II: Documents in the State Archives, Palermo, No. 1, Cancelleria Regia: 1259-1400 (Malta: Malta University Press, 1999), documents 171, 172 and 249; No. 2, Cancelleria Regia: 1400-1459 (Malta: Malta University Press, 2004), documents 58, 176 and 313 .

9 The archive of the Roman Inquisition and Apostolic Delegation in Malta (1561-1798) is among the most complete to have survived. It is further enriched by much of the original correspondence sent from Malta to the papal Secretariat of State and the Congregation of the Holy Office. The Secretariat of State correspondence also includes the foglietti di notize discussed below.
} 
private individuals, generally for a three-year period. Prior to the setting up of printing facilities on the island this was to remain the standard procedure through which the island's paper requirements were met. ${ }^{10}$

The general European tendency towards the creation of more streamlined bureaucratic structures where both state and Church were concerned ${ }^{11}$ in the Maltese context resulted in the first traced attempts to set up printing facilities on the island during the 1630s. ${ }^{12}$ The Hospitaller state's need to maintain regular contacts with its mainland European lifeblood, where it held its wealth and from where its members were recruited, was a crucial added motivation. From the very start, the state resorted to the use of the press to project itself to the European audience, mainly through the printing of adulatory accounts of its achievements against the Muslim foe. ${ }^{13}$ Local printing was also, however, motivated by a rising demand from the local business and literate classes. Initially intended to be set up in the form of a state monopoly, issues pertaining to censorship with Rome induced the order to allow the establishment of a printing press in the form of a private, albeit still monopolistic initiative in 1642. Persisting differences over the control of its output, however, were to result in its closure just fifteen years circa following its opening. Its limited traced printed output has been studied from a bibliographic but also from a physical point of view, including the paper's provenance. The latter revealed that the paper for the earliest Maltese press was produced in Messina and Amalfi, with other sources remaining unidentified. ${ }^{14}$

Well into the eighteenth century, the island remained practically the only sovereign European state lacking printing facilities, with all the ensuing limitations that this entailed from the administrative, commercial and cultural perspectives, even if the connections established by then somehow facilitated the use of foreign printing presses for specific local needs and the importation of material of a more generic nature. ${ }^{15}$ The dependence on foreign paper supplies thus extended to any form of printed product,

${ }^{10}$ Mdina Cathedral Archives (MCA henceforth), Archive of the Inquisition Malta, Memorie section, vols. 2 and 15, containing the various monopolistic contracts for the importation of paper, starting from the seventeenth century down to the mid-eighteenth, with some gaps.

11 On the evolution of state bureaucracies across cultures, see PAUL M. DOVER, ed., Secretaries and Statecraft in the Early Modern World (Edinburgh: Edinburgh University Press, 2016); for a discussion of the differentiation of spaces and practices of European archives, see RANDOLPH C. HEAD, 'Configuring European Archives: Spaces, Materials and Practices in the Differentiation of Repositories from the Late Middle Ages to 1700,' European History Quarterly 46, no. 3 (2016): 498-518.

12 William Zammit, Printing in Malta, 1642-1839: Its Cultural Role from Inception to the Granting of Freedom of the Press (Malta: Gutenberg Publishers, 2008), chapter 1.

13 Thus, to give one example, in 1644, copies of the locally printed account of the order's naval victory of September 28 of that year were sent to Rome to be reprinted there and further disseminated, so that, in Grand Master Lascaris's own words 'Essendo stampata la relatione del combattimento [...] ve ne mandiamo alcune copie, affinchè possiate pubblicarle in cotesta Corte, e venghi risaputo per mezzo loro il successo in detto combattimento, e quanto sangue consti alla nostra Religione una tal impresa'; ZAMMIT, Printing in Malta, 302, n. 53.

14 MArius CINI, 'Technical Analysis and Documentation of Seventeenth-Century Works Printed in Malta,' (unpublished dissertation: Institute for Conservation \& Restoration Studies, Malta Centre for Restoration, 2003), 25-49.

15 A parallel may be drawn here with the examples discussed by PABLO SÁNCHEZ LEÓN in Print Culture and Peripheries in Early Modern Europe, ed. BeniTo Rial Costas (Leiden and Boston: Brill, 2013), 1-30. 
comprising even basic administrative and business literature. It was only in 1756, following an agreement reached with the Holy See regarding censorship procedures, that printing was re-established, this time under a firm and permanent state monopoly. ${ }^{16}$ While tightly controlled through a triple censorship mechanism resulting in a press which reinforced the political, religious and social status quo, the presence of local printing after 1756 undoubtedly resulted in the availability of a far greater amount of print in circulation than ever before. As in 1642, while the primary motivation for setting up printing facilities resulted from the state's administrative and propaganda requirements, the press was also heavily used by private individuals to satisfy a variety of needs, including those of the ever-expanding business community.

The surviving records of the eighteenth-century Maltese press constitute some of the most complete for an early modern state-owned facility. They allow not only for a detailed bibliographic study of its printed output and general functioning, but even more significantly in the context of the present study - of the variety, sources, amount and use of paper imported for the press. ${ }^{17}$ Paper of different, specified types was imported mainly from Ancona, Comiso, France, Genoa, Naples and Venice, with their respective costs being given. ${ }^{18}$ Besides its utilisation for the satisfaction of printing commissions, the press was to assume the role of becoming practically the exclusive supplier and distributer of paper on the island, substituting the old system of private importation on a contractual basis. ${ }^{19}$ Very significantly, the presence of local printing facilities from 1756 onwards not only enabled the consolidation of the local print culture and an increased dependence on it, but also allowed the press to become the main supplier of paper as the raw material for the satisfaction of all script-related communication both within and beyond the island.

\section{The Rise of a Paper-Dependent Maltese Business Class}

The greater integration of the Maltese economy with that of other Mediterranean regions started early on but picked up especially following the victory of 1565 over the Ottoman force that besieged Malta. ${ }^{20}$ The traditional commercial ties with Sicily, mainly concerning the annual importation of foodstuffs and other basic necessities imports of food and basic necessities - experienced a dramatic expansion, both in terms of sheer volume and the variety of commercial transactions. This of course

16 ZAMMIT, Printing, 45-88.

17 National Library of Malta (NLM henceforth), Archive of the Order of Malta (AOM henceforth) volumes 2038 to 2071 consist of the surviving registers of the state press, including the annual registers listing every single printing commission and all of the press income and expenditure. These have been summarised in STANLEY FIORINI and WILLIAM ZAMMIT, Catalogue of the Records of the Order of St John of Jerusalem in the National Library of Malta: Volume XIII, 2038-2071 (Malta: University of Malta, 1990).

${ }^{18}$ FIORINI and ZAMMIT, Catalogue, viii.

19 AOM volumes 2038 to 2063, consisting of the annual press registers covering the period 1756 to 1781 and 1791 to 1793 . The registers for 1782 to 1790 and 1794 to 1798 are missing. Substantial sales of paper of various types to other government departments and private entities were recorded under 'Introiti Diversi' (Miscellaneous Receipts). The wealth of detail provided by these registers regarding paper quality and the amounts that were imported to be used either by the press itself or sold to third parties calls for in-depth study.

20 ABELA, Hospitaller Malta, 4. 
necessitated and was reflected in a parallel increase in paper-based finance. Maltese and foreign traders in a variety of staple but also increasingly luxury goods operated from Malta, particularly from the expanding harbourside towns, and maintained regular communication with their suppliers in Italy, France and Spain, among other countries.

Together with the Hospitaller Order's massive revenues which poured into the island, it was cotton exports that sustained the island's ever-increasing population and balance of payments. A Maltese Chamber of Commerce had been established by the first decades of the eighteenth century, in part to regulate the export of this cash crop. ${ }^{21}$ Meanwhile, quite substantial Maltese migrant commercial communities had been established throughout much of the Western Mediterranean. Thus, to give one example, a total of 396 Maltese merchants were operating from various parts of Spain during the sample years 1764 to 1766, with the vast majority being in Cadiz (191) and Valencia (99). ${ }^{22}$ Similar Maltese commercial communities thrived in Pachino, ${ }^{23}$ Marseilles $^{24}$ and Ragusa (modern-day Dubrovnik). ${ }^{25}$ The Maltese commercial presence abroad was also reflected in the expansion of the island's consular representation. ${ }^{26} \mathrm{~A}$ major alternative to commerce was corsairing. Prosperous Maltese families invested in corsairing activities on a considerable scale, some of them, like the Preziosi family, making a fortune in the process. ${ }^{27}$

Both regular trade and legalised piracy in the form of corsairing similarly required the creation and maintenance of a vast array of documentation, examples of which have survived in substantial numbers. Pride of place in this respect goes to the notarial archive. Situated in Valletta and containing hundreds of thousands of notarial deeds covering the late fifteenth to the end of the eighteenth centuries and beyond, the archive is only now being catalogued so that its contents may be comprehensively researched. Nevertheless, even in its current state, a study of trade activity on the island during the second half of the eighteenth century has revealed its richness in this respect. ${ }^{28}$ The archive's impressive holdings of documents in the form of commercial contracts, loans, insurance deeds, inventories of cargo and of corsairing booty, and the

${ }^{21}$ MCA, Miscellanea 153, ff. 102-3.

22 VASSALLO, Corsairing, 56.

23 Rosa Savarino, Terra Compita: Pachino, una colonia maltese nella Sicilia del Settecento (Palermo: edizioni Verbavolant, 2014); ARnold Cassola, Malta-Sicily: People, Patriots, Commerce (1770-1860) (Syracuse: Morrone editore, 2016).

${ }^{24}$ In 1792 the Maltese community in Marseilles returned to Malta due to the upheavals of the French Revolution. Archivio Apostolico Vaticano, Segreteria di Stato, Malta, vol. 148, f. 221, Inquisitor ScottiSS, dated August 2, 1792: 'Coll'ultimo bastimento di Francia sono qui ritornate alcune famiglie maltesi stabilite in Marsiglia fin da molti anni.'

25 MASsimo PEZZI, 'La “congiura” maltese del 1749 nei documenti diplomatici ragusei,' Studi Melitensi 25 (2017): 53-76.

26 Carmel Vassallo, 'The Consular Network of XVIII Century Malta,' in Proceedings of History Week 1994 (Malta: Malta Historical Society, 1996), 51-62.

27 The literature on Maltese corsairing activities is vast; however, the economic aspect still requires attention. A classic in this respect remains PETER EARLE, Corsairs of Malta and Barbary (London: Sidgwick \& Jackson, 1970), 97-191.

${ }_{28}^{28}$ John DebonO, Trade and Port Activity in Malta, 1750-1800 (Malta: The Author, 2000). Debono's work relies very heavily on material held at the Malta Notarial Archive. 
whole variety of commercial paperwork in the form of bills of exchange, bills of lading and customs literature, attest to the increasing dependence on different and evolving typologies of trade documentation. A related, vast and even less explored archival fond is that pertaining to the records of the various Maltese courts of law operating during the period. Particularly relevant are those of the Consolato del Mare. Set up in 1697, the records of this maritime tribunal attest to the regular utilisation of what were by then fast becoming standardised forms and ephemera, whether still in manuscript format, or, increasingly, in print. Among others, manifests and safe conducts pertaining to shipping leaving the Maltese harbour abound. ${ }^{29}$ By way of contrast, not much seems to have survived of the original Monte di Pietà archive. While primarily intended to provide modest loans, secured by pawned goods, the Monte could also be utilised for raising a moderately higher capital to be used in commercial transactions beyond the island's shores and this again created the need for standardised printed forms, examples of which have also be found in collections outside Malta. ${ }^{30}$

All the above constitute public archival repositories which, by their very nature, are usually lacking when it comes to trade-related correspondence of a private nature. A number of the early modern trading families of Malta have survived and are known to possess substantial family archives. These, however, are only exceptionally open for research and their contents remain mostly unknown. One exception is the large archive pertaining to the Bonavita family which has been passed over to the University of Malta. The Bonavita archive spans the seventeenth to the nineteenth century and contains printed and manuscript trade-related paperwork concerning the family's business interests. ${ }^{31}$ More family business archives are nevertheless gradually being opened for study. A classic in this context is the amazing fond recording the business translations of Simón Ruiz. Ruiz (1525-97) settled in Medina del Campo in the heart of Castile, from where he conducted and expanded his commercial empire throughout much of Europe. The collection of letters received from his agents in Malta alone, covering the period 1575 to 1591 , total over eighty, constituting the largest known collection for this period in Malta. ${ }^{32}$

\footnotetext{
29 Vassallo, Corsairing to Commerce, 13; Sebastian Vella, 'The Bureaucracy of the Consolato del Mare in Malta (1697-1724),' in Consolati di Mare and Chambers of Commerce: Proceedings of a Conference Held at the Foundation for International Studies (Valletta, 1998), ed. CARMEL VASSALLO (Malta: Malta University Press, 2000), 69-80.

${ }^{30}$ DAVID RossI, 'The Monte di Pietà in Hospitaller Malta' (unpublished BA (Hons) dissertation, Faculty of Arts, University of Malta, 1998).

31 Roger Vella Bonavita, 'The Bonavita Papers: One Method of Preservation,' in Maltese History: What Future? Proceedings of a Conference held at the Royal University of Malta on 19 and 20 March 1971, eds ANN Williams and Roger Vella Bonavita (Malta: Malta University Press, 1974), 156-60.

32 I consulted this collection, held at the Simón Ruiz Archive in Medina del Campo, on a short-term scientific mission within the COST Action 'People in Motion' project, and I am currently working on the material. A word of appreciation is here due to Prof. José María Pérez Fernández who alerted me to the Maltese material in this archive and to Antonio Sánchez del Barrio, Director of the Archive and his staff, particularly Fernando Ramos Gonzáles, for their most generous assistance.
} 


\section{Some Major Typologies of Maltese 'Print in Motion'}

Limited use of such staple business-related literature as bills of exchange, lading and health goes back to at least the second half of the sixteenth century. Nevertheless, they experienced an elaboration in format and a very considerable increase in demand during the following two centuries.

Bills of exchange constituted one of the commonest financial instruments when it came to carrying out transactions with traders outside Malta as well as for the repayment of foreign-based loans. This is clearly evidenced by the Maltese material in the Ruiz collection which contains a good number of early bills of exchange originating from Malta. Similar early examples have been tracked down in the Maltese notarial archive, with one going back to $1540 .{ }^{33}$ Their use in manuscript form remained generally prevalent until the advent of printing facilities on the island, when they started to be printed regularly and in sustained amounts:

\begin{tabular}{|c|c|c|c|}
\hline Date of printing & Description & Client & Print run \\
\hline October 5, 1756 & Polize di cambio mercantili & Gioacchino Arena & $\mathrm{nda}^{34}$ \\
\hline October 23, 1756 & Polize di cambio & Gioacchino Arena & nda \\
\hline October 23, 1756 & Polize di cambio & Gioacchino Arena & nda \\
\hline January 15, 1757 & Polize di cambio & Giuseppe Fenech & nda \\
\hline January 17,1757 & $\begin{array}{l}\text { Polize di cambio, parte de'quali in } \\
\text { francese e parte in italiano }\end{array}$ & Giuseppe Fenech & nda \\
\hline June 8,1757 & Polize cambiali & Gioacchino Arena & nda \\
\hline June 21, 1757 & Polize di cambio & Gioacchino Arena & nda \\
\hline November 191757 & Polize di cambio & Gioacchino Arena & nda \\
\hline February 7,1758 & Polize cambiali a'giorno & The Printing Press & 500 \\
\hline July 13,1758 & Polize cambiali ad'uso & The Printing Press & 500 \\
\hline October 4, 1758 & Polize cambiali seconde & Gioacchino Arena & nda \\
\hline January 31,1759 & Ricevute o'siano polize di cambio & Giuseppe Crenna & nda \\
\hline August 9, 1760 & Polize cambiali & Gaspare Maurin & nda \\
\hline December 1760 & Polize cambiali & Giuseppe Crenna & nda \\
\hline 1768 & Cambiali & Gioacchino Sauron & nda \\
\hline May 3, 1769 & Cambiali & $\begin{array}{l}\text { Gioacchino Arena and Antonio } \\
\text { Poussielgues }\end{array}$ & 515 \\
\hline May 10, 1769 & Cambiali & Federico Vella (Press employee) & nda \\
\hline July 26, 1769 & Cambiali & Federico Vella (Press employee) & nda \\
\hline December 29, 1773 & Cambiali & Federico Vella (Press employee) & nda \\
\hline
\end{tabular}

33 JOAN ABELA, 'Some Early Forms of Financial Instruments found in Mid-Sixteenth Century Malta,' in Storja: 30 th Anniversary Edition, 1978/2008, ed. HENRY Frendo (Malta: Malta University Historical Society, 2008), 38.

34 No data available. That said, the recorded consumption of paper for their printing indicates a substantial print run. 
PAPER, COMMERCE, AND THE CiRCUlATION OF NEWS

\begin{tabular}{|c|c|c|c|}
\hline 1774 & Polize di cambio & Vincenzo Micallef & nda \\
\hline 1774 & Polize di cambio & Antonio Poussielgues & nda \\
\hline 1774 & Cambiali & Federico Vella (Press employee) & 134 \\
\hline 1774 & Polize di cambio & Federico Vella (Press employee) & 140 \\
\hline 1775 & Cambiali & The Printing Press & nda \\
\hline 1775 & Polize di cambio & The Printing Press & nda \\
\hline 1775 & Cambiali & The Printing Press & nda \\
\hline 1779 & Cambiali & Antonio Poussielgues & nda \\
\hline June 1,1791 & Cambiali & nda & nda \\
\hline March 26, 1792 & Cambiali & nda & nda \\
\hline
\end{tabular}

Figure 1. The printing of bills of exchange in Malta: 1756-1798. ${ }^{35}$

The survival of the detailed original printing press records thus confirms the sustained use of printed bills of exchange, actual copies of which are often found in collections outside the island. The different wording used in their description may indicate variants, examples of which still need to be traced. The major traders on the island, foremost among whom was d'Arena, commissioned such bills regularly. As practised elsewhere, the printing press itself printed material in regular demand which it then sold at a profit. The absence of commissions between 1782 and 1790 and again between 1794 and 1798 is due to the fact that the annual press registers for those years have not survived. The bills of lading used by Maltese shipping followed a similar trend, though imported printed specimens were often resorted to prior to 1756 :

\begin{tabular}{|c|c|c|c|}
\hline Date of printing & Description & Client & Print run \\
\hline 1758 & Polize di carico & The Printing Press & nda \\
\hline October 25,1760 & Polize di carico & The Comptroller of Customs Giorgio Grognet & nda \\
\hline 1760 & Polize di carico & The Printing Press & nda \\
\hline February 11,1761 & Polize di carico & The Printing Press & nda \\
\hline February 17,1762 & Polize di carico & The merchant Basilio Cognidi & nda \\
\hline 1767 & Polize di carico & Federico Vella (Press employee) & nda \\
\hline October 3,1772 & Polize di carico & Antonio Poussielgues & nda \\
\hline 1776 & Polize di carico & nda & nda \\
\hline May 11,1778 & Biglietti di carico & Leonardo Cognidi \\
\hline
\end{tabular}

Figure 2. The printing of bills of lading in Malta: $1756-1798 .^{36}$

35 FIORINI and ZAMMIT, Catalogue, data collated from the original annual press registers.

${ }^{36}$ FIORINI and ZAMMIT, Catalogue, data collated from the original annual press registers. 
Printed Maltese bills of health preceded the availability of printing in Malta by well over a century. Moreover, given their very nature, they constituted by far the most widely available category of 'print in motion' between the Hospitaller state, the Mediterranean region and at times well beyond. By way of contrast with travel patents, bills of health were issued to all those travelling outside the island, confirming they had left the island without any traces of contagious disease. Hence, they were printed in vast quantities. ${ }^{37}$ Given the rapid increase in travel and thus the considerable quantities required, Maltese bills of health started being commissioned from foreign printing presses well before 1756, with the earliest printed specimen traced as yet being dated 1713. From 1756 onwards, vast quantities of the documents were printed locally, constituting a major and regular commitment for the modest local press:

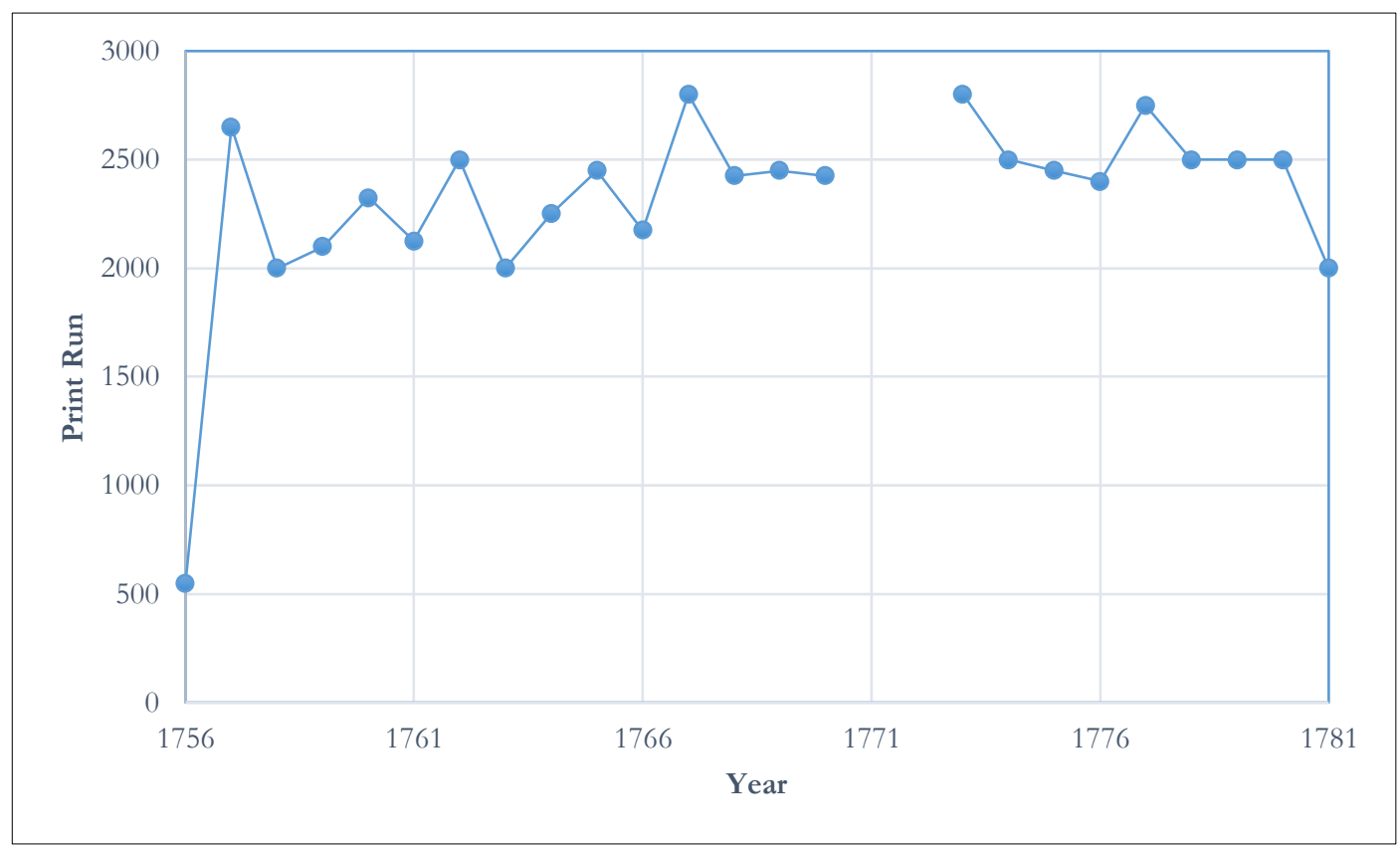

Figure 3. The printing of bills of health in Malta: $1756-1781 .^{38}$

As in the case for the previously presented data, the unrepresented years 1782 to 1790 and 1794 to 1798 are due to the lack of the original press registers, while the lack of bills of health printed in the years 1791 to 1793 remains rather inexplicable.

\footnotetext{
${ }^{37}$ For a discussion of another form of travel document in the Maltese context, namely the travel patent, see IAn F. HATHAWAY, 'Informing, Controlling, Protecting: Sixteenth-Century Mediterranean Travel Patents as Vehicles of Diplomatic and Administrative Communication' (Paper presented during the COST PIMo Granada Conference held on January 28-29, 2021).

${ }^{38}$ FIORINI and ZAMMIT, Catalogues, collated from the original annual press registers.
} 
Printed currency convertors constituted a vital novelty when it came to finance-related printed literature on the island. The expansion of Maltese imports and exports had resulted in a considerable variety of foreign currencies of fluctuating value circulating on the island. These usually comprised Sicilian, Neapolitan, Roman, Venetian, Spanish, Portuguese and French denominations for which the currency convertors provided the equivalent in Maltese currency. The demand for such convertors was such that they started to be printed locally, quite regularly in considerable print runs, until the gradual elimination of foreign currencies from local circulation during the early nineteenth century. ${ }^{39}$ In this case too, raw material and technology would enable the vast number of financial transactions characterising Malta's eighteenth-century multinational economy.

\section{The Evolution of Text and Iconography}

While generally speaking the written content of bills of exchange, lading and health underwent little change once rendered into a printed form, the same can hardly be said for the decorative elements that characterised this paper in transit. ${ }^{40}$ The essentially private nature of bills of exchange may explain their plain, unadorned format, with no visual religious or state reference, at least until the end of the order's rule. It was during the first decades of the nineteenth century that vignettes depicting sea-related scenes and particularly a shield and trident-holding image of Britannia made its way onto these purely private and utilitarian prints. As for the written format, it remained practically identical, apparently being copied from its predecessor.

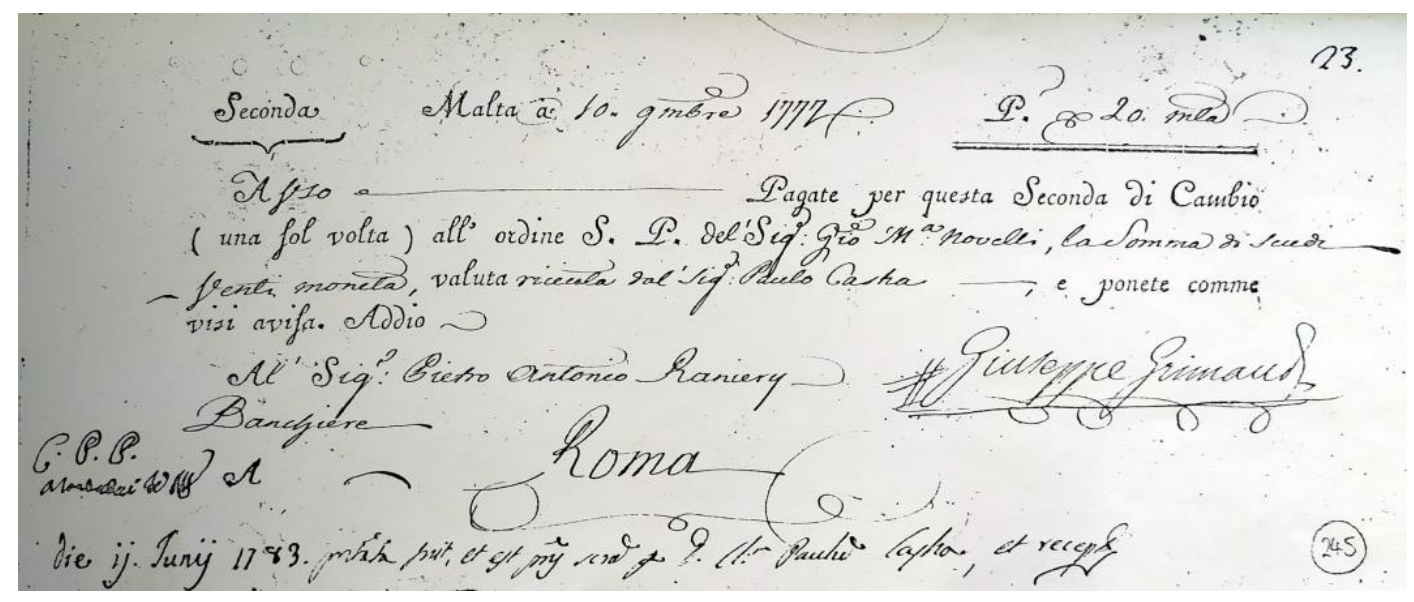

Figure 4. A 'Malta' bill of exchange dated 1777. Private collection, Malta.

39 Such currency convertors are known to have been printed locally in 1756, 1758, 1765, 1775, 1780, 1790 and 1811.

40 Giovanni Bonello, 'Maltese 19th Century Commercial Instruments and their Adornment,' in Histories of Malta: Passions and Compassions, vol. X (Malta: Fondazzjoni Patrimonju Malti, 2009), 116-39. 
Bills of lading constituted a more value-laden document, in terms of both the written and the iconographical content. ${ }^{41}$ The printed text invariably commenced and ended with an invocation to God for the safe arrival of the vessel and its contents at the port of destination. All such bills examined, dated between 1746 and 1816, carried this invocation in a practically identical format. ${ }^{42}$ The main body of the text then proceeded, as in the case of bills of exchange, in a standard legal jargon aiming to cover all eventualities which could lead to the loss or damage of the registered merchandise. This also underwent little by way of refinement during the same period. Generic bills of lading from 1746 and 1813 carrying cargo destined for Malta, but without specifying the port of origin in print, bore naive woodblock vignettes depicting the Virgin Mary (1746) and the saints Marcian and Lucy, both patron saints of Syracuse (1813). Interestingly, a rare surviving example printed in Malta (1758) and also specifying the Maltese harbour as that of departure did not feature any religious symbolism, while it did bear the coat of arms of the reigning Grand Master Pinto de Fonseça. Another example from the Maltese press used in 1763 does not feature any printed imagery at all. Subsequent traced Malta-related bills of lading utilised between 1812 and the 1860s only bore generic engravings of shipping, mythological scenes related to the sea and occasionally views of the Maltese harbour, with no religious or overtly political iconography whatsoever. ${ }^{43}$

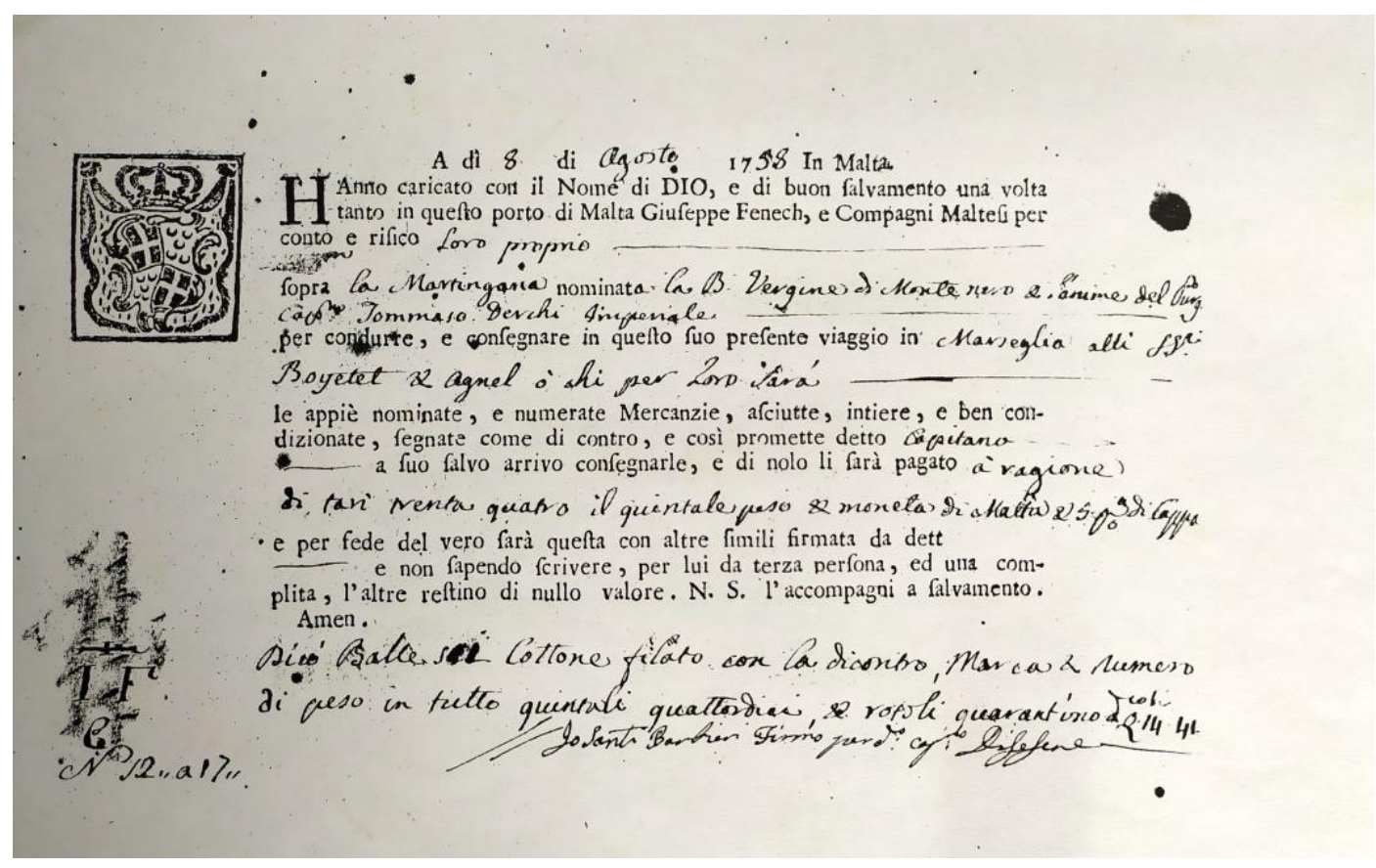

Figure 5. A 'Malta' bill of lading dated 1758. National Archives, Malta.

${ }^{41}$ Charles Goldie, 'The Bill of Lading Then and Now,' in Consolati di Mare, 3-13.

42 Thus, the example from 1746 starts with: 'Ha Caricato con il nome di DIO, e di buon salvamento' and ends with: 'Nostro Signore l'accompagni in salvamento.' Practically identical phrases are to be found printed on examples dated 1758, 1813 and 1816.

43 BONELlo, 'Maltese 19th Century,' 122-37. 
The physical size and format of the bills of health provided a much larger space for the inclusion of decorative and symbolic visual elements. From the earliest one traced, down to the end of the Hospitaller rule, bills of health consisted of a large copperplate engraving, varying in size but roughly equivalent to the modern A2 size. Notwithstanding the fact that thousands were printed in Malta during the second half of the eighteenth century (Figures 7 and 8), they are seriously, though understandably, rare to come by, with only a handful of examples traced as yet. Like the other two major types of printed commercial literature discussed above, they consisted of a form, in this case bearing the seal of the Castellan, namely the highest health authority on the island. The individual's name and age, together with the name of the vessel on which the person was embarking and date of issue, were added to the form. Some of the specimens examined list more than one individual. The printed text certified that the travellers were not known to be suffering from any communicable disease at the point of departure.

Three main distinct copperplate bill of health patterns have hitherto been identified from the Hospitaller period. While the text remained practically unaltered throughout, the imagery was subject to some changes. The earliest, rather crude specimen traced so far was issued on September 16, 1713 and bears Grand Master Perellos' (1697-1720) coat of arms in the top centre, flanked by a panoply of military trophies and with an image of St. John the Baptist and St. Paul on the left and right sides respectively, both saints also being invoked to keep the island free from plague or any other epidemic (see Figure 6). The inclusion of those two saints bears particular significance, the former being the patron saint of the Hospitaller Order, while the latter was that of the island-principality over which the same order ruled. This symbolic identification of the order with Malta constituted nothing less than a widely disseminated visual political statement: the expansion of the order's sovereign political claims over the island - essentially being granted as a fiefdom and ultimately remaining under Sicilian suzerainty - were increasingly being questioned and at times resisted both by foreign powers, particularly Naples, but also by the Maltese themselves. It is indeed likely that this depiction emphasising the Hospitaller Order's untrammelled claim over Malta constituted the most widely distributed one outside the island, remaining a staple, prominent feature on bills of health until the end of the order's rule. The figures of Justice and Bounty flanking the coat of arms similarly constituted permanent visual statements of the grand masters' power and benevolence. 


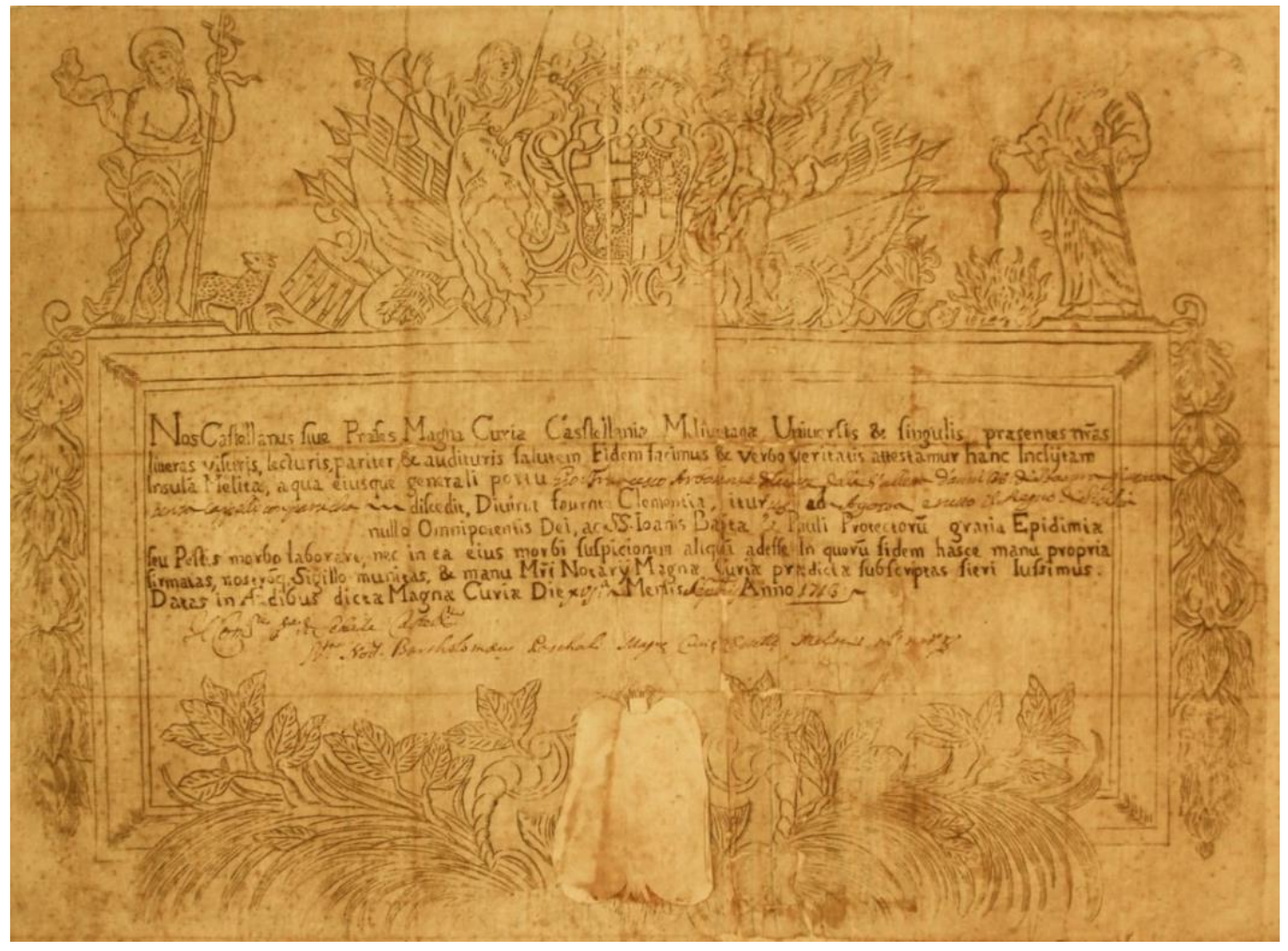

Figure 6. The Perellos bill of health dated 1713. National Museum of Art, Malta (MUŻA) collection.

The Perellos template formed the basis for the second known bill, dating from Grand Master Pinto's magistracy (1741-73, see Figure 7). A traced example was issued on February 28, 1766. A more artistically refined engraving, the Pinto bill of health also featured a map of the Maltese harbours with its fortifications. A copperplate from Pinto's successor, Ximenez de Texada (1773-75), confirms the retention of the Pinto plate, with only the two quarters of Pinto's coat of arms being re-modelled into those of Ximenez. ${ }^{44}$ This is also confirmed by the identical plate size.

The third variant copperplate was the one produced during Grand Master de Rohan's magistracy (1775-97). The only known engraving to bear the names of its designer and engraver, the de Rohan bill of health is by far the most competently executed of them all. ${ }^{45}$ For some reason, the use of this plate was short-lived, being succeeded by a considerably poorer copy which remained in use into the late 1790 s. ${ }^{46}$

\footnotetext{
44 NLM, Libr. MS 1083, f. 15.

45 NLM, Libr. MS 704A, f. 444, dated April 5, 1781.

46 NLM, Libr. MS 703, f. 49, dated 1796.
} 


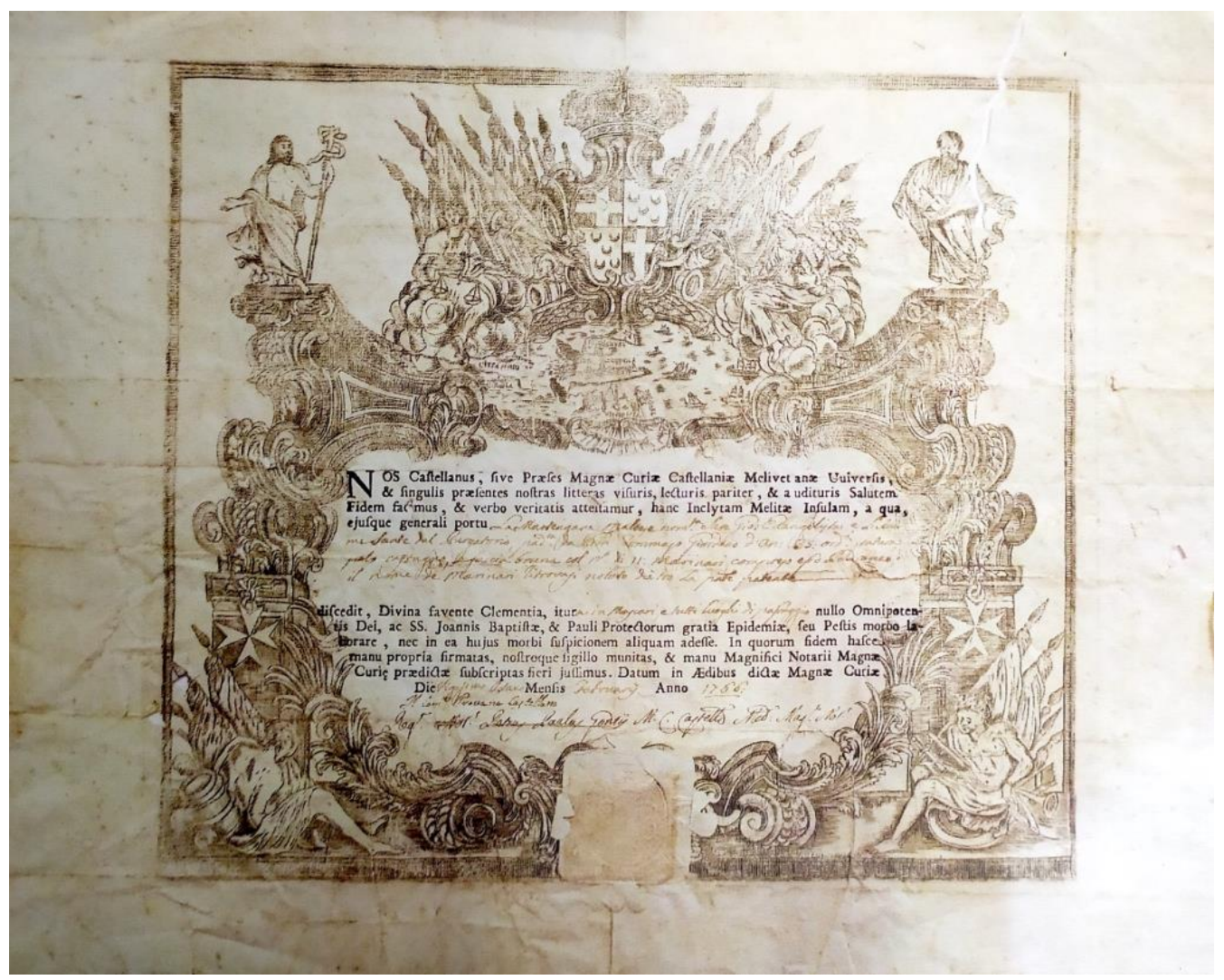

Figure 7. The Pinto bill of health dated 1766. National Museum of Art, Malta (MUŻA) collection.

\section{Malta and the Circulation of News in the Mediterranean and Beyond}

In the Maltese context the evolution of the three main typologies of early modern communication, namely oral, visual and written, was a direct result of the very considerable expansion of interactions with the outside world. While, of course, the initial impact was felt in the rapidly expanding harbour conurbation, imported news, ideas and fashions did reach, at least to some extent, the island's rural areas. The archival record provides extensive confirmation of this: new and often unorthodox ideas even reached villagers in the remoter areas, while the visual communication of might in the form of secular and religious spectacle was similarly emulated, particularly but not exclusively, through the elaboration of village parish cults during the eighteenth century. The low levels of literacy pervading early modern Mediterranean societies resulted in oral and visual communicative means assuming paramount importance; indeed, even paper-based interaction was often image- rather than script-dependent. It is thus within this overall wider communicative context that the expansion in the amount as well as the variety of paper communication both within and beyond the island's shores needs to be discussed. 


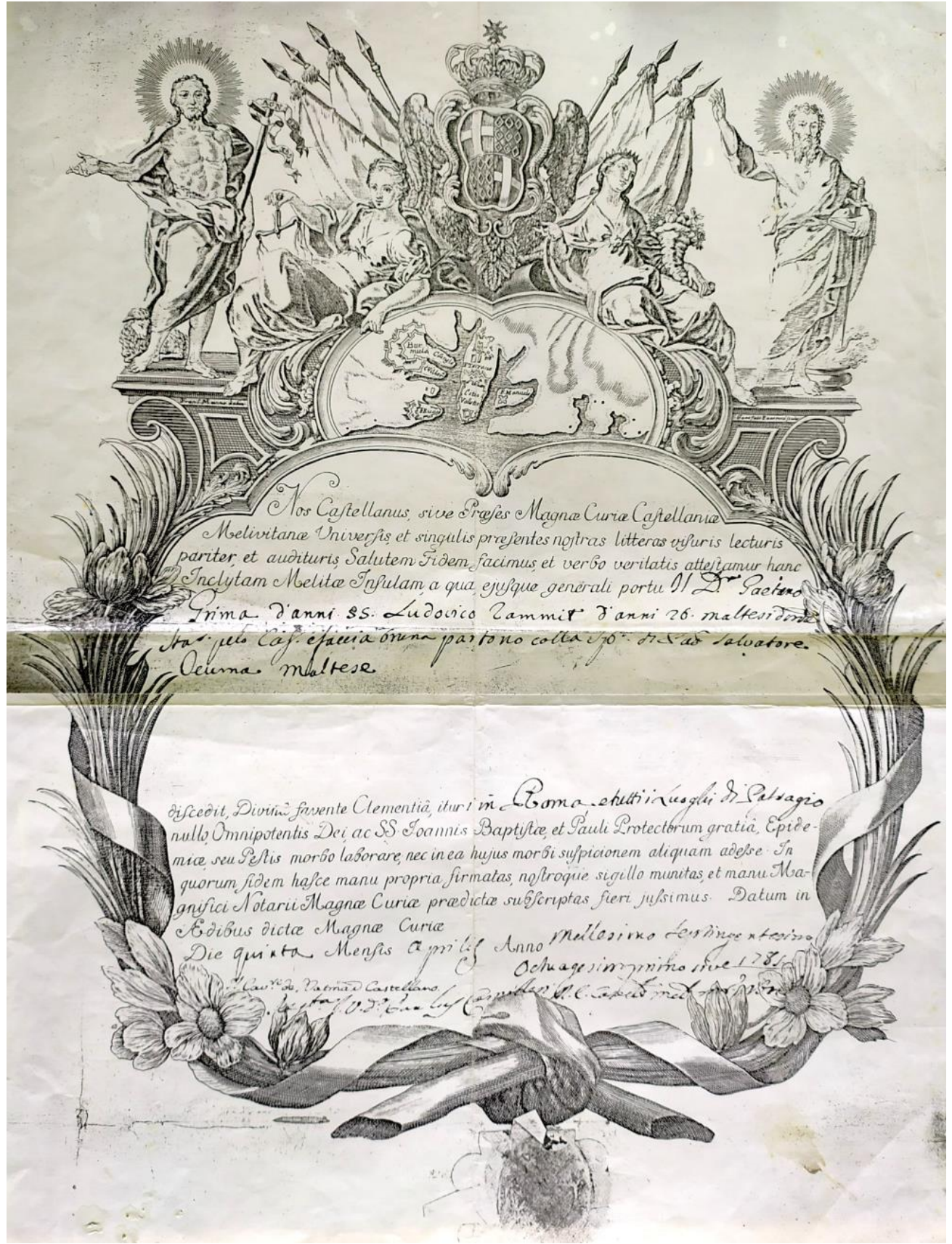

Figure 8. The de Rohan bill of health dated 1781. National Library of Malta collection.

Given the presence of the multinational Hospitallers on the island, together with an increasing number of other foreigners and consulates on the island, Malta became a centre for the receipt and dissemination of factual news about the great and the mighty, but also of rumour and hearsay originating from well beyond the island's shores. The exchange of written correspondence with the continent was - as well as the case of verbal conversation with foreign visitors - a major means for the acquisition of current 
information and opinion. This was at times disseminated in such a way as to reach a very substantial part of the local illiterate population. ${ }^{47}$ The divulgation of information obtained was at times motivated by the satisfaction of particular interests. In 1755, for instance, Inquisitor Salviati circulated the information he had received regarding the deathbed conversion of Montesquieu using all means at his disposal. ${ }^{48}$ Letters reached the island either through ships stopping at its harbour or through the order's own postal system which employed ships specifically for the transport of letters. Members of the order eagerly awaited correspondence from their native country and the arrival of letters was generally greeted with enthusiasm. The arrival and despatch of correspondence was always subject to the vagaries of the weather ${ }^{49}$ and to the depredations caused by corsairing activity. ${ }^{50}$ Notwithstanding temporary delays, however, the flow of correspondence reaching the island was, given the order's presence, very considerable, both in amount and in the diversity of origin and hence of the information, opinions and ideas contained. ${ }^{51}$

In their role of apostolic delegates, inquisitors in Malta were regularly reminded by the papal Secretariat of State of their duty to gather any news concerning events taking place in Malta as well as along the Mediterranean littoral and much further afield too, and to pass it over to the central authority in Rome. This was particularly emphasised in times of crises, such as during an Ottoman onslaught. ${ }^{52}$ In the vast majority of cases such news was not included in the formal correspondence itself, but in the extremely valuable news-sheets or confidential foglietti di notizie compiled by the

${ }^{47}$ For example, AAV, SS Malta 51, f. 242, Inquisitor Messerano-SS, dated September 18, 1700: ‘[...] la sudetta feluca portò lettere d'Italia assai fresche, dalle quali con giubileo di tutta l'Isola si è inteso che Nostro Signore si ristabilisca nella salute.'

48 AAV, SS Malta 122, f. 178r-v, Inquisitor Salviati-SS, dated June 9, 1755: 'I chiari contrassegni di ravvedimento, e di ritrattrazione dell'erronee sue massime dati prima del passaggio all'altra vita del celebre Presidente di Montesquieu fanno veramente conoscere quanto sia grande, ed in tutte le opere sue amirabile la misericordia del Signore. Io ne ho letto con infinito piacere la relazione del Padre Bernardo Rothè, che Vostra Eminenza si è degnata benignamente trasmettermi, e non ho lasciato di comunicarla a diversi principali Signori, con spargerne anche varie copie, affinchè maggiore sia lodata la Divina Bontà nella divolgazione di un avvenimento così maraviglioso.'

${ }^{49}$ For example, AAV, SS Malta 58, f. 31, Inquisitor Spinola-SS, dated February 6, 1706: 'Cresce sempre più l'impatienza di questi nazionali francesi, che da gran tempo sono senza lettere de' loro paesi'; f. 59v, dated March 13, 1706: 'Siamo tutta via senza nuove per la parte di Francia, attesa la scarsezza de' bastimenti capitate da quelle parti'; f. 275, Inquisitor Caracciolo-SS, dated October 30, 1706: 'Continua in quest'Isola la mancanza delle lettere dalla Sicilia'; 125, f. 163, Inquisitor Salviati-SS, dated January 2, 1759: 'La stagione contraria ha impedito finora il ritorno da Siracusa della Barca speditavi da questo Balì Combraux, Agente del Re di Francia per prendere i dispacci'; 146, f. 7, Inquisitor Scotti-SS, dated January 9, 1789: 'La contrarietà de' tempi impedisce l'arrivo di bastimenti, e massime Francesi, onde ricever interessanti notizie sugli oggetti vertenti per questa Religione in quel Regno.'

${ }^{50}$ For example, AAV, SS Malta 53, f.222, Inquisitor Messerano-SS, dated August 6, 1702.

${ }^{51}$ For example, AAV, SS Malta 65, f. 339, Pro-Inquisitor Napulone-SS, dated March 5, 1718: 'Oggi a punto arrivò la Barca speronara delle lettere da Reggio, e porta quattro dispacci con molte novità del mondo'; 80, f. 18, Inquisitor-SS, dated January 24, 1739: 'Coll'arrivo qua fatto da vari bastimenti provenenti dalle Parti di Ponente, sono capitate fresche lettere ad alcuni di questi Signori Cavalieri Spagnoli'; f. 39v, dated February 21, 1739: '[...] con lettere pervenute da Marsiglia a diversi di questi Cavalieri francesi.'

52 Johann Petitjean, 'The Papal Network: How the Roman Curia Was Informed about SouthEastern Europe, the Ottoman Empire and the Mediterranean (1645-1669),' in News Networks in Early Modern Europe, eds JOAD RAYMOND and NOAH MOXHAM (Leiden; Boston: Brill, 2016), 178-92. 
inquisitors themselves thanks to the information network that the Holy Office maintained in Malta. ${ }^{53}$ The news-sheets were attached to the formal inquisitorial dispatches and contained a motley of news, from Malta or indeed from any part of the globe, of which the apostolic delegate deemed Rome should be aware. ${ }^{54}$

Confidential in nature and based on the variety of sources that were accessible to such a powerful institution as the tribunal of the Roman Inquisition in Malta, the foglietti di notizie fulfilled the role of any printed news-sheet literature - which in any case did not exist in Malta - to perfection. Malta's position was admirably suited for this purpose in more ways than one. The island's geographical but also its political and, increasingly so, its commercial situation provided the Hospitaller state with all the ideal credentials to act as a lieu de passage, a place of discursive interaction, and thus potentially a main supplier of news to the papacy. Inquisitors in Malta, residing practically on the shore of Malta's Grand Harbour, were kept regularly supplied with the news constantly flowing into Malta from the ever-increasing amount of naval and commercial shipping originating from all corners of the Mediterranean and beyond. Thus, running parallel to the ever-flourishing commerce in goods was the equally as vital trade in events, rumours and suspicions, resulting in what Pettegree refers to as 'the exponential growth of news reporting' during the period. ${ }^{55}$ The Maltese harbour did not simply evolve into a centre for entrepôt trade: with no less equal vigour, it assumed the role of news-broker, a cosmopolitan babel where an amazing kaleidoscope of news available on a first- or second-hand basis and hence always subject to factual error and construed interpretation - was eagerly sought, translated, bartered, exchanged and passed on, even if it was inevitably somewhat distorted in the process. ${ }^{56}$

It is in this context that the foglietti di notizie constitute a most remarkable and possibly unique corpus of factual data, observations and running commentaries on practically every aspect of life in Malta and beyond between the mid-seventeenth century and the last decades of eighteenth, ending of course with the demise of what may perhaps best be described as the Old Regime phase of Maltese history. ${ }^{57}$ Not only

${ }^{53}$ For a discussion of 'avvisi secreti' and 'avvisi pubblici', see Paul Arblaster et al., 'The Lexicons of Early Modern News,' in News Networks, ed. Raymond and Moxham, 67.

54 While register copies were kept of the formal dispatches themselves, many of which still survive in the archive of the Inquisition in Malta, no copies of the news-sheets seem to have been made and so the originals in the Archivio Apostolico Vaticano are unique.

55 ANDREW PetTegree, The Invention of News: How the World Came to Know About Itself (Yale University Press, 2014), 5.

${ }^{56} \mathrm{On}$ the various aspects of oral communication in early modern Malta, ZAMMIT, The Dissemination, I, 7-30. See also IVAN GrECH, 'Struggling Against Isolation: Communication Lines and the Circulation of News in the Mediterranean: the Case of Seventeenth-Century Malta', Journal of Mediterranean Studies 16, no. 1 (2006): 163-74.

57 The original correspondence between inquisitors in Malta and the papal Secretariat of State is held in the Malta section of the Secretariat of State's archival fond, held in the Vatican Apostolic Archive. The section contains a total of 186 volumes, spanning the second half of the sixteenth century down to the end of the eighteenth. The regular series of original correspondence starts with Inquisitor Gori Pannellini in May 1645 and ceases with Inquisitor Carpegna in September 1795. The fond also contains other volumes of a miscellaneous nature which include pre-1645 and post-1795 material from Malta, as 
is the chronological span of the coverage impressive: a striking blend of news, varying from the strictly internal political machinations that moved inexorably following the demise of the grand master-cum-sultan and the sombre funerary rites that followed, to the commissioning of artistic works; from natural calamities to naval victories; and from descriptions of pious acts to horrific crimes and even more blood-curdling descriptions of the state's vengeful retribution that inevitably followed. News from Persia reached Malta as early as 1629 and was duly transmitted to Rome, as were other reports that described events in Muscovy and Baghdad in $1700{ }^{58}$ When news-sheets were unusually concise or indeed totally lacking, it was felt that some justification was required. Inclement weather and hence a paucity of ships calling at the Maltese harbour was often a reason for this. ${ }^{59}$ On other occasions, however, a laconic statement would express surprise at the fact that newly arrived shipping did not bear any intelligence as to what was going on beyond the shores of the miniscule island-state. ${ }^{60}$ The typology and extent of the information contained in the notizie varied very considerably from one inquisitor to another and this explains why, for some particular years, more information on crime is available. Inquisitors such as Gerolamo Casanate (1658-63), Giacinto Ferrero de Messerano (1698-1703) and Paolo Passionei (1743-54) are a historian's delight when it comes to crime reporting, given the number of cases they described. During the latter's tenure, the failed revolt of the slaves was unravelled, and the Inquisitor's reporting of the blood-curdling saga as it developed between May 1749 and March 1751 constitutes a major primary source, vividly describing not just the framework of events but more importantly the feelings of shock, fear and indignation and the resulting sense of self-righteousness and justification in meting out what even back then was seen as horrific punishment. ${ }^{61}$ In contrast, Passionei's successor, Gregorio Salviati (1754-59), seems to have been more concerned with providing Rome with news concerning practically every corner of the world, rather than with local goings-on. Together with the order's printed relazioni, avvisi and ragguagli, the

well as ciphers from Malta and drafts of letters from the Secretariat of State addressed to inquisitors and others in Malta.

58 Biblioteca Apostolica Vaticana (BAV henceforth), Barberini Latino (Barb. Lat. henceforth) 6678, f. 65 Inquisitor Herrera, dated April 17, 1629; AAV, SS Malta 51, f. 213, Inquisitor Messerano, dated August 7, 1700 .

59 AAV, SS Malta 37, f. 4, Inquisitor Caracciolo, dated January 16, 1686: 'Pochi bastimenti qui giunti dalla Sicilia, et una tartana da Marsiglia non portano alcuna curiosità da riferirsi'; 79, f. 321, Inquisitor Durini, dated December 27, 1738: 'Attesa la stravaganza de'tempi, che qua corre, non è comparso in questa settimana alcun bastimento nel Porto, anche si rimane privo di novità di Levante, e d'ogni altra Parte.'

60 Thus, AAV, SS Malta 65, f. 343, Pro-Inquisitor Napulone, dated December 25, 1717: 'In questa settimana comparve un piccolo vascello inglese ... quale arriva in questo general porto da Inghilterra [...] non da novità del mondo'; 75, f. 51v, Inquisitor Durini, dated February 16, 1732: 'Da molto tempo il porto non e stato così pieno di bastimenti, ma nulladimeno le nuove sono assai scarse.'

${ }_{61}$ My major study on the 1749 Plot of the Slaves and Inquisitor Passionei's description thereof is currently in press. 
inquisitorial foglietti thrive within the wider context of Behringer's detailed discussion of the concept of early modern 'communications revolutions. ${ }^{\text {'62 }}$

The officially regulated seaborne postal service between Malta and mainland Europe utilised the existing postal infrastructure once it reached the European mainland. ${ }^{63}$ The service was run by the state, primarily for the satisfaction of its own requirements. It was, however, also available for use by other institutions and the population at large. The state's control over the only organised public postal system linking the island with the European mainland was a valuable weapon in the struggle for supremacy over the other contenders to power, particularly the Inquisition. State centralisation led to surveillance, both of which characterised various other European postal systems. ${ }^{64}$ It was one which was increasingly resorted to by the more absolutistminded grand masters, notably de Vilhena and Pinto. The non-regularity of the service throughout the eighteenth century thus resulted as much from fortuitous circumstances as from political considerations. Inquisitorial correspondence invariably took over a month - at times well over that - to reach its destination. ${ }^{65}$ In times of conflict with the Inquisition, the state could use all possible means at its disposal to prevent the despatch of inquisitorial correspondence to Rome. In extreme cases, not only was the state postal service made unavailable to the Inquisition, but the latter's attempt to utilise alternative means was similarly obstructed. Occasionally, this could include the searching of merchandise on private shipping suspected of carrying inquisitorial correspondence and the prohibition of vessels from carrying any letters not registered with the government. The Inquisition would, in such circumstances, have no option but to rent out a ship at its own expense for the despatch of its correspondence and have it manned by inquisitorial patentees upon whom the state could exercise no authority. ${ }^{66}$ At the height of the various disputes between Inquisitor Stoppani and Grand Master de Vilhena, the government was accused of intentionally delaying the despatch of post to Rome for nearly two months, specifically to prevent inquisitorial correspondence from reaching that destination while, at the same time,

62 Wolfgang Behringer, 'Communications Revolutions: A Historiographical Concept,' German History 24, no. 3 (2006): 333-74.

63 This is discussed by Nikolaus Schobesberger et al., 'European Postal Networks,' in News Networks, ed. RAYMOND and MOXHAM, 59-61.

64 SCHOBESBerger et al., 'European Postal Networks', especially 60-61.

${ }^{65}$ For example, AAV, SS Malta 60, f. 134, Inquisitor Caracciolo-SS, dated March 31, 1708; f. 344, dated July 28, 1708.

${ }^{66}$ For example, AAV, SS Malta 53, f. 21 r-v, Inquisitor Messerano-SS, dated January 14, 1702: 'Provo anche se mi riesce di far giunger' quest'umilissima mia all'Eccellenza Vostre per la quarta con simile, che furtivamente, e con somma fretta tento di spedire già che tirannicamente mi s'impediscono tutte le strade da poter mandar costì le mie lettere [...] Haveva già consegnato il mio dispaccio ad un Bergantino ... e gli fu sequestrata la mercanzia per haver prese le mie lettere. Fu poi da questo Governo fatto un rigorosissimo ordine, che tutti i legni di partenza non debbano prender lettere di alcuno, che non ne diano relazione, e che non le portino in segretaria Magistrale. Vedendo ciò, presi a mie spese una barca, e per marinari di essa i miei barcaruoli, e familiari, e pure con altri vari palliati pretesi ieri fu impedita de' partire, dicendosi, che si voleva, che la detta mia barca benchè spedita à mie spese, con i miei barcaruoli sopra, per servizio di Nostro Signore, aspettasse che fosse all'ordine il dispaccio del Governo, senza portare il quale non sarebbe mai partita.' 
creating inconvenience to all. ${ }^{67}$ The use of such politically motivated tactics in the manipulation of the postal service continued during Pinto's magistracy and beyond, with delays at times lasting months on end. ${ }^{68}$ These delays did not disrupt the state's own correspondence since the latter had its own alternative means of sending and receiving despatches. ${ }^{69}$

The government's manipulation of the postal service remained a reality until the end of the order's rule. ${ }^{70}$ Delaying tactics were not the only obstacles to the delivery of correspondence. The use of the official postal system required its users to deliver their despatches to the grand master's secretariat and this always raised fears of governmental tampering. ${ }^{71}$ As a countermeasure, the more sensitive inquisitorial correspondence was invariably written in cipher. The order was not the only political entity that interfered with the delivery of letters. In 1714 it was reported that all correspondence arriving in Sicily from Rome was opened and if found to contain anything touching upon the Kingdom of Naples, withheld and its deliverers illtreated. ${ }^{72}$ The disruption in communications as a result of the dispute between the order and the Kingdom of Naples between 1753 and 1755 resulted in perhaps the most serious interruption of correspondence between Malta and the continent during the century. Indeed, the effects of this disruption were still being felt following the reopening of commercial ties between the two sides. ${ }^{73}$

\section{Conclusion}

The aim of this case study has been to broadly highlight the role played by specific typologies of manuscript and print in the transformation of an erstwhile isolated and culturally archaic Mediterranean community into the context of an economically and culturally thriving European microcosm. Self-containment gave way to connectivity. Of course, the main reason was the 'political accident' of 1530. It was indeed this accident that vastly increased the need for written exchanges of all sorts. The introduction of printing provided the Hospitaller Order with an effective means to

${ }^{67}$ AAV, SS Malta 75, f. 18r-v, Inquisitor Stoppani-SS, dated January 19, 1732: 'Vuole Vostra Eminenza col pregiatissimo suo foglio de' 15 dello spirato, che io mi assicuro nel sospetto già da me concepito, che il commercio delle lettere con Roma non si ritardi solamente dall'avversità della stagione, ma talvolta per qualche privata ragione [...] Da ciò presi motivo di risolvergli alla spedizione di una Barca a mie spese, e mi riuscì in tal guisa di riconvenire civilmente la negligenza del Governo, e di svegliarlo alla spedizione della solita speronara del Dispaccio, che da quasi due mesi si tratteneva oziosa in Porto con susurro, e pregiudizio di tutta l'Isola, che attribuiva l'artificiosa tardanza alle note mie differenze col Governo sudetto'; 76, f. 57, dated February 7, 1733.

68 AAV, SS Malta 122, f. 100, Inquistor Salviati-SS, dated March 17, 1755: 'Doppo 5 mesi che era stata levata la posta, si è veduto finalemente affisso il Cartello per la prossima partenza della barca con il pubblico dispaccio.'

${ }^{69}$ Cassar, 'The Diplomatic Courier,' 29-30.

${ }^{70}$ AAV, SS Malta 149, f. 8, Inquistor Carpegna-SS, dated January 21, 1796: 'La posta differita da questo governo sino a giovedì venturo.'

71 AAV, SS Malta 61, f. 533, Pro-Inquisitor Napulone-SS, dated May 17, 1710.

${ }^{72}$ AAV, SS Malta 63, f. 493v, Inquisitor D'Elci-SS, dated June 9, 1714.

73 AAV, SS Malta 122, f. 90v, Inquisitor Salviati-SS, dated March 10, 1755: 'Il commercio riaperto della Sicilia non si puol dire, che sia ancora risultato di alcun vantaggio a quest'Isola, nè quanto al sostanziale de' viveri, nè quanto al reciproco trasporto delle lettere.' 
develop its administrative hold over the island, but also to promote itself to its European patrons. Equally crucial was the increased availability of commercial print, enabling the transformation from an essentially agrarian economy to one in which trade played a very significant role by 1798 .

The exchange of goods, but also of politically relevant factual news, rumours, hearsay, as well as opinions, ideas and values, increased dramatically as channels of communication improved and political interest in the Mediterranean and beyond increased. At the local level, the political, religious and commercial elites sought to consolidate and expand their respective base of political and economic power. In all this, the role of paper in its different manuscript, printed or pictorial manifestations played an enormous, if as yet generally underrated role. 